\title{
First record of Diaphus rafinesquii (Cocco, 1838) (Myctophidae) in the Norwegian Sea
}

\author{
Rupert M. Wienerroither' and Otte Bjelland
}

\begin{abstract}
Wienerroither RM and Bjelland O. 2013. First record of Diaphus rafinesquii (Cocco, 1838) (Myctophidae) in the Norwegian Sea. Fauna norvegica 32: 39-43.

The myctophid Diaphus rafinesquii is endemic in the North Atlantic and the Mediterranean and was for the first time found in the Norwegian Sea. The specimen was captured off northern Norway at about $71^{\circ} \mathrm{N}$, representing the northernmost record so far. Meristic and morphometric comparisons showed no evident differences to specimens found in other areas of its distribution. Although the actual abundance and distribution of this species in Norwegian waters remained unclear, we emphasized the general high potential of mesopelagic species for indicating environmental short- and long-time changes by monitoring the faunal change.
\end{abstract}

doi: 10.5324/fn.v31i0.1528. Received: 2012-05-31. Accepted: 2012-10-08.

Published on paper and online: 2013-02-13.

Keywords: mesopelagic, lanternfish, Norway, northeastern Atlantic, Myctophiformes

1. Institute of Marine Research, P.O. Box 1870, 5817 Nordnes, Bergen, Norway

Corresponding author: Rupert M. Wienerroither

E-mail: rupert@imr.no

\section{INTRODUCTION}

As resource of minor commercial value, mesopelagic species and especially their taxonomic diversity suffer often of a lack of attention. Although the shift in distribution of eastern North Atlantic commercial and non-commercial species has been investigated and partly been attributed to the warming sea temperature (Brander et al. 2003, Perry et al. 2005), mesopelagic species have not been part of the investigations. Pelagic fishes are affected to a larger extent by ecological factors of the open water, and should therefore respond quickly to temperature changes and thus provide a good source for monitoring the effects of global warming, both on shortand long-term changes (Byrkjedal et al. 2004, Rose 2005). Knowledge about changes in their distribution and abundance is therefore crucial.

Myctophidae is one of the two dominant families in the mesopelagic realm, both in terms of species and individuals (Gjøsæter \& Kawaguchi 1980). Abundance and diversity are highest in tropical and subtropical waters but decrease towards higher latitudes (Gjøsæter \& Kawaguchi 1980, Hulley
1981). Diaphus Eigenmann \& Eigenmann, 1890 is the most speciose genus within the family Myctophidae, comprising 78 species (Eschmeyer 2012), of which 23 occur in the North Atlantic (Nafpaktitis et al. 1977, Froese \& Pauly 2012). These are primarily found in tropical and subtropical waters, only Diaphus rafinesquii (Cocco, 1838) and Diaphus metopoclampus (Cocco, 1829) occur regularly in the temperate waters of the eastern North Atlantic north of $50^{\circ} \mathrm{N}$ (Hulley 1984). Diaphus rafinesquii is endemic in the North Atlantic and Mediterranean and has a temperate-semisubtropical distribution pattern with occurrence between $20^{\circ}$ and $56^{\circ} \mathrm{N}$; isolates are found in the eastern North Atlantic to $62^{\circ} \mathrm{N}$ (Nafpaktitis et al. 1977, Hulley 1984). The abundance is highest in the Mediterranean, the northern Mauritanian Upwelling and the temperate part of the North Atlantic (Nafpaktitis et al. 1977, Hulley 1981). The species performs diel vertical migrations and is usually found below $400 \mathrm{~m}$ during day. In the Atlantic adults remain below $300 \mathrm{~m}$ during night, whereas juveniles can be found at 40-200 m (Nafpaktitis et al. 1977).

We report in this paper the first finding of Diaphus 
rafinesquii in Norwegian waters, summarize its taxonomical characters, and thus hope to strengthen the interestin mesopelagic fishes. We further compare meristic and morphometric data to specimens from the western North Atlantic (Nafpaktitis et al. 1977), the eastern North Atlantic (Hulley 1984), and the Mediterranean (Cihangir et al. 2003).

\section{MATERIAL AND METHODS}

A bottom trawl was employed aboard the IMR (Institute of Marine Research) vessel "Johan Hjort" near the margin of the continental shelf, off northern Norway in depths between 387 and $410 \mathrm{~m}$. The net used was a shrimp trawl (Campelen, 1800 meshes, with rockhopper gear, straps, $20 \mathrm{~mm}$ meshes in the cod-end and sweep wires of $40 \mathrm{~m}$ ), the average vertical opening was $4.1 \mathrm{~m}$. Identification followed Nafpaktitis et al. (1977) and Hulley (1984). The specimen was preserved in $5 \%$ formalin and subsequently in $70 \%$ ethanol, a tissue sample in $96 \%$ ethanol. The specimen and the tissue sample were deposited at the University Museum of Bergen (Norway) under the accession number ZMUB 20854. A digital caliper was used for morphometric measurements which followed the definitions of Hubbs \& Lagler (2004). Abbreviations of the photophores (luminous organs) followed Nafpaktitis et al. (1977).

\section{RESULTS}

The specimen (figure 1) was captured on 1 March 2009, around 1645 hours, just at sunset, off northern Norway, $70^{\circ} 55.1^{\prime} \mathrm{N}$, $17^{\circ} 12.8^{\prime} \mathrm{E}$ (figure 2). It suffered some damages (loss of scales, broken finrays), but was generally in good condition enabling a clear identification. Taxonomic characters of the genus Diaphus are (1) the presence of at least one pair of luminous organs on head, and (2) the arrangement of the photophores $\mathrm{PO}_{1}, \mathrm{PVO}_{1}$ and $\mathrm{PVO}_{2}$ as well as $\mathrm{VO}_{1}, \mathrm{VO}_{2}$ and $\mathrm{VO}_{3}$ in an ascending oblique line. Main characters separating the species from congeners are: (1) So present, (2) Vn long, wide and bifurcating anteriorly, (3) AOa highly elevated, and (4) a large luminous scale at PLO (figure 1). The latter is the reason for the established English common name "White-spotted lanternfish" and the proposed Norwegian common name "Hvitflekklysprikkfisk". Meristic data and morphometric measurements are given in table 1 . The total body mass is biased by the damages and was therefore not taken. Meristics of the present specimen are consistent with data given in the literature (Nafpaktitis et al. 1977, Hulley 1984, Cihangir et al. 2003). Table 2 compares the morphometric measurements with data from the same literature. The specimen was not opened but the rather large $\mathrm{Vn}$ indicates that it is male. The nearby measured water temperature from the surface to $300 \mathrm{~m}$ depth ranged from 6.3 to $6.8^{\circ} \mathrm{C}$. No other myctophid or

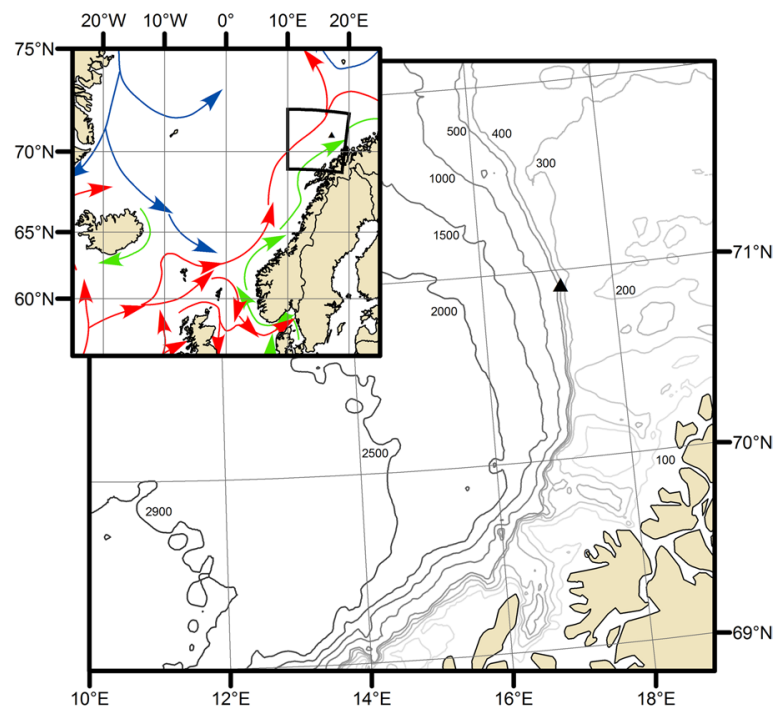

Figure 2. Map showing the capture site ( $\mathbf{\Delta}$ ) of Diaphus rafinesquii and the general pattern of currents in the eastern North Atlantic (red arrows: Atlantic water, blue arrows: Arctic water, green arrows: coastal water).

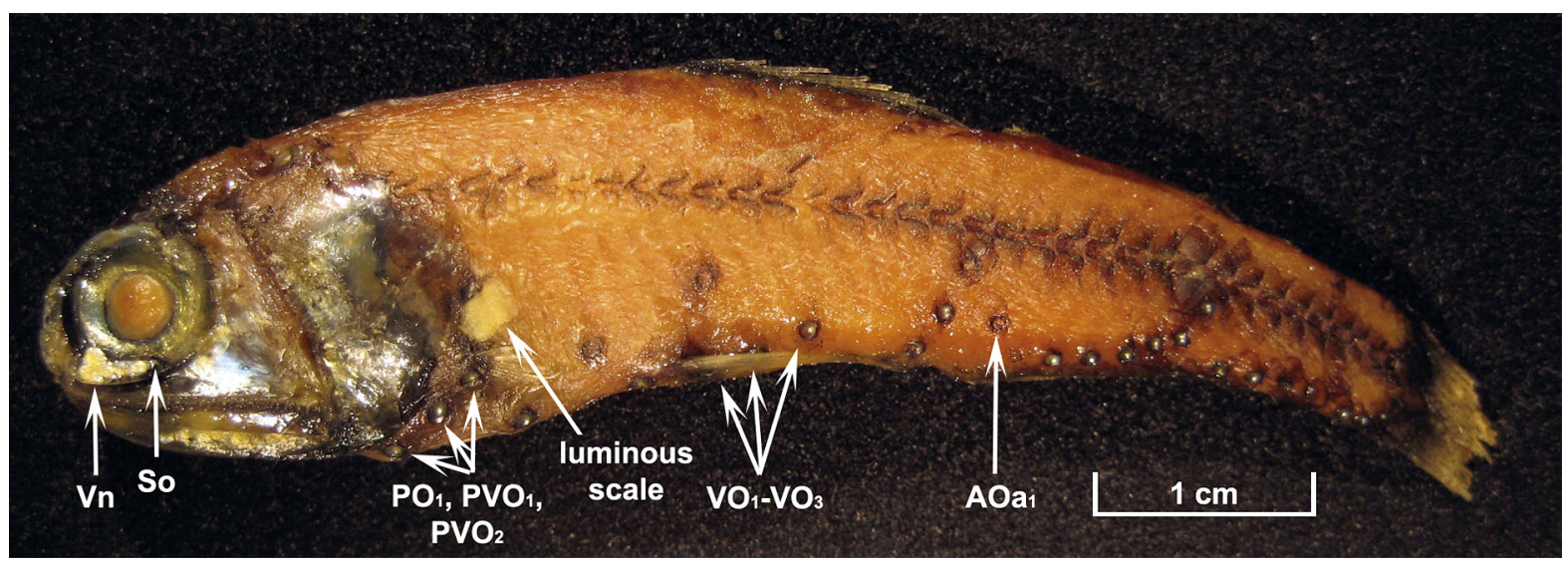

Figure I. Diaphus rafinesquii (ZMUB 20854) captured off northern Norway. The arrows indicate the main taxonomic characters of the species (see text for further explanations). Photo: Rupert Wienerroither. 
Table I. Meristic and morphometric (in $\mathrm{mm}$ ) data of Diaphus rafinesquii.

\begin{tabular}{|c|c|c|c|c|}
\hline & Present specimen & Hulley 1981 \& Hulley 1984 & Nafpaktitis et al. 1977 & Cihangir et al. 2003 \\
\hline dorsal finrays & 13 & $13(12-14)$ & $13-14$ & 14 \\
\hline anal finrays & 15 & $14(13-15)$ & $13-14(15)$ & 14 \\
\hline pectoral finrays & 10 & $10(9-11)$ & 10-11 & 10 \\
\hline pelvic finrays & 8 & & & 8 \\
\hline gill rakers & $8+1+15$ & $7-8+1+14-15(13-16)$ & $7-8+1+14-15(16)$ & \\
\hline $\mathrm{AOa}$ & 7 (left), 6 (right) & $6(5-7)$ & $6(5-7)$ & \\
\hline AOp & 4 & $4(3-5)$ & $4(3-5)$ & \\
\hline lateral-line organs & 35 & & $35-36$ & 35 \\
\hline standard length & 61.29 & & & $79.30-84.11$ \\
\hline head length & 17.79 & & & $19.35-20.42$ \\
\hline interorbital width & 6.47 & & & $7.13-8.79$ \\
\hline length of orbit & 6.30 & & & $4.83-6.12$ \\
\hline depth of caudal peduncle & 6.11 & & & \\
\hline length of caudal peduncle & 11.12 & & & \\
\hline dorsal fin base & 11.45 & & & 18.01-18.99 \\
\hline anal fin base & 11.09 & & & $14.43-15.76$ \\
\hline body depth at anal fin origin & 10.43 & & & \\
\hline body depth at dorsal fin origin & 13.51 & & & \\
\hline body depth & & & & $21.35-22.66$ \\
\hline head depth & 13.48 & & & \\
\hline predorsal length & 29.26 & & & $30.52-32.86$ \\
\hline snout length & 1.30 & & & $2.09-2.71$ \\
\hline upper jaw length & 12.42 & & & \\
\hline preanal length & 38.87 & & & \\
\hline head width & 8.15 & & & \\
\hline
\end{tabular}

mesopelagic species was caught during the same trawl haul.

\section{DISCUSSION}

The present specimen marks the northernmost record of Diaphus rafinesquii at almost $71^{\circ} \mathrm{N}$, exceeding a specimen caught south of Iceland at $61^{\circ} 55^{\prime} \mathrm{N}$ (Nafpaktitis et al. 1977, Hulley 1984, Jónsson \& Pálsson 2006). Most of the morphometric measurements lie within the ranges given in the literature. However, as the methods of how these were taken are not given, comparisons are difficult to make. The especially high deviations of two values (length of orbit and snout) are more likely due to differing measuring methods than to actually differing body proportions.

The origin of the specimen is unknown, but due to the complex vertical migration behavior of many mesopelagic fishes, anthropogenic reasons for the occurrence of such species outside their known distribution area can be regarded as implausible. Natural displacement seems therefore to be the most likely explanation. Between 2004 and 2008 the snake pipefish Entelurus aequoreus (Linneaus, 1758) was found in the southern and western part of the Barents Sea (Wienerroither et al. 2011) and other areas of the northeastern Atlantic (Kirby et al. 2006, Fleischer et al. 2007, Rusyaev et al. 2007). This temporary occurrence was linked to higher water temperatures (Kirby et al. 2006, Fleischer et al. 2007, Rusyaev et al. 2007), which might also have had an effect on the occurrence of other fish species like the present one. Anyway, Philippart et al. (2011) predict that southern species are likely to invade the Nordic Seas and thus increase the biodiversity within the fish communities, with some species becoming frequent visitors. For most open seas, there is evidence of species moving northwards with a shift in species composition, which means for northern seas, like the Norwegian Sea, from polar to more temperate species (Philippart et al. 2011). Perry et al. (2005) examined the change of distribution of North Sea species as response to an increased sea temperature in the course of 25 years. They found that species shifting their distribution northward had a faster life cycle and smaller body size than non-shifting species. 
Table 2. Comparision of morphometric data of Diaphus rafinesquii.

\begin{tabular}{|c|c|c|c|}
\hline & Present specimen & Nafpaktitis et al. 1977 & Cihangir et al. 2003 \\
\hline number of specimens & 1 & 11 & 4 \\
\hline standard length (mm) & 61.29 & $66.5-83$ & $79.30-84.11$ \\
\hline area & Norwegian Sea & Gulf of Mexico & Aegean Sea \\
\hline \multicolumn{4}{|l|}{ in standard length } \\
\hline head length & 3.45 & $3.08-3.28$ & $3.9-4.2$ \\
\hline dorsal fin base & 5.35 & & $4.2-4.6$ \\
\hline anal fin base & 5.53 & & $5.1-5.5$ \\
\hline body depth at dorsal fin origin & 4.54 & & \\
\hline body depth at anal fin origin & 5.88 & & \\
\hline body depth & & & $3.6-3.9$ \\
\hline predorsal length & 2.09 & & \\
\hline \multicolumn{4}{|l|}{ in head length } \\
\hline upper jaw length & 1.43 & $1.4-1.5$ & \\
\hline interorbital width & 2.75 & & $2.3-2.9$ \\
\hline length of orbit & 2.82 & $2.6-3$ & $3.3-4.2$ \\
\hline snout length & 13.68 & & $7.5-9.3$ \\
\hline \multicolumn{4}{|l|}{ in upper jaw length } \\
\hline length of orbit & 1.97 & $1.8-2$ & \\
\hline
\end{tabular}

Although their investigation was based on bottom fishes, results might also be applied on mesopelagic species, which are generally small in size and have even less habitat constraints. However, Byrkjedal et al. (2004) conclude that new records of previously not reported mesopelagic species in the west of the British Isles are more likely due to an increased sampling effort than to a poleward range extension. The net used during this survey was not designed for the capture of mesopelagic species and this was not the intention either. Moreover, it is uncertain in which depth the specimen was caught, it could have entered the net when it was on the way down or up. The single finding gives therefore no information about the actual abundance and distribution of $D$. rafinesquii in the area covered by the present or similar surveys carried out by IMR.

Pethon (2005) reports five species of Myctophidae in Norwegian waters: Benthosema glaciale (Reinhardt, 1837), Lampanyctus macdonaldi (Goode \& Bean, 1896), Myctophum punctatum Rafinesque, 1810, Notoscopelus kroyeri (Malm, 1861), and Protomyctophum arcticum (Lütken, 1892). Only $B$. glaciale is known to be reproducing in Norwegian waters with populations in the open sea and the fjords (Kristoffersen \& Salvanes 2009), whereas the other species are regarded as more or less frequent visitors. Although there is no reason to doubt this categorization, information about the abundance and distribution of these species as well as of $D$. rafinesquii and other mesopelagic species in Norwegian waters must be regarded as fragmentary. This is in spite of the huge potential that mesopelagic fishes provide not only for studies in biodiversity, but also as an indicator for environmental changes by monitoring the changes in faunal composition.

\section{ACKNOWLEDGMENTS}

We are very grateful to Inger Marie Beck (IMR) for collecting the specimen and an anonymous reviewer for valuable comments on the manuscript.

\section{REFERENCES}

Brander K, Blom G, Borges MF, Erzini K, Henderson G, MacKenzie BR, Mendes H, Ribeiro J, Santos AMP, Toresen R. 2003. Changes in fish distribution in the eastern North Atlantic: Are we seeing a coherent response to changing temperature? ICES Marine Science Symposia 219: 261-270.

Byrkjedal I, Godø OR, Heino M. 2004. Northward range extension of some mesopelagic fishes in the Northeastern Atlantic. Sarsia 89: 484-489.

Cihangir B, Tirasin EM, Ünlüoglu A, Benli HA, Bizsel KC. 2003. New records of three deep-sea fishes: Diaphus rafinesquei, Lobianchia gemellarii (Myctophidae), Notolepis rissoi (Paralepididae) from the Aegean Sea (Turkish coast). Journal of Ichthyology 43(6): 486-489.

Eschmeyer WN (ed.). Catalog of Fishes electronic version. Published: 2012-03-12. Accessed: 2012-04-27. http://research. calacademy.org/research/ichthyology/catalog/fishcatmain.asp. 
Fleischer D, Schaber M, Piepenburg D. 2007. Atlantic snake pipefish (Entelurus aequoreus) extends its northward distribution range to Svalbard (Arctic Ocean). Polar Biology 30: 1359-1362.

Froese R, Pauly D (eds.). FishBase. World Wide Web electronic publication. Published 2012-04. Accessed: 2012-04-27. www. fishbase.org.

Gjøsæter J, Kawaguchi K. 1980. A review of the world resources of mesopelagic fish. FAO Fisheries Technical Paper 193. 151 p.

Hubbs CL, Lagler KF. 2004. Fishes of the Great Lakes Region. Revised edition by Smith GR. The University of Michigan Press. 276 p.

Hulley PA. 1981. Results of the research cruises of FRV "Walther Herwig" to South America. LVIII. Family Myctophidae (Osteichthyes, Myctophiformes). Archiv für Fischereiwissenschaften 31: 1-300.

Hulley PA. 1984. Myctophidae. In: Whitehead PJP, Bauchot M-L, Hureau J-C, Nielsen J, Tortonese E (eds). Fishes of the North-eastern Atlantic and the Mediterranean. Unesco, Paris. pp 429-483.

Jónsson G, Pálsson J. 2006. Íslenskir fiskar. Vaka-Helgafell, Rejkavik. 336 p.

Kirby RR, John DG, Lindley JA. 2006. Fathers in hot water: rising sea temperatures and a Northeastern Atlantic pipefish baby boom. Biology Letters 2: 597-600.

Kristoffersen JB, Salvanes AGV. 2009. Distribution, growth, and population genetics of the glacier lanternfish (Benthosema glaciale) in Norwegian waters: Contrasting patterns in fjords and the ocean. Marine Biology Research 5: 596-604.

Nafpaktitis BG, Backus RH, Craddock JE, Haedrich RL, Robison BH, Karnella C. 1977. Family Myctophidae. Fishes of the Western North Atlantic. Memoir of the Sears Foundation for Marine Research 1(7): 13-265.

Perry AL, Low PJ, Ellis JR, Reynolds JD. 2005. Climate Change and Distribution Shifts in Marine Fishes. Science 308: 19121915.

Pethon P. 2005. Aschehougs store fiskebok. Aschehoug, Oslo. $468 \mathrm{p}$.

Philippart CJM, Anadón R, Danovaro R, Dippner JW, Drinkwater KF, Hawkins SJ, Oguz T, O'Sullivan G, Reid PC. 2011. Impacts of climate change on European marine ecosystems: Observations, expectations and indicators. Journal of Experimental Marine Biology and Ecology 400: 52-69.

Rose GA. 2005. On distributional responses of North Atlantic fish to climate change. ICES Journal of Marine Science 62: 1360-1374.

Rusyaev SM, Dolgov AV, Karamushko OV. 2007. Captures of Snake Pipefish Entelurus aequoreus in the Barents and Greenland Seas. Journal of Ichthyology 47:544-546.

Wienerroither R, Johannesen E, Dolgov A, Byrkjedal I, Bjelland O, Drevetnyak K, Eriksen KB, Høines Å, Langhelle G, Langøy H, Prokhorova T, Prozorkevich D, Wenneck T. 2011. Atlas of the Barents Sea Fishes. IMR/PINRO Joint Report Series 1-2011, ISSN 1502-8828.
Editorial responsibility: Torkild Bakken.

This article is open-access and distributed under the terms of the Creative Commons Attribution-Noncommercial 3.0 Unported License (http://creativecommons.org/licenses/by-nc/3.0/). This permits all non-commercial use, distribution, and reproduction in any medium, provided the original work is properly cited. 